\title{
IMPLICATIONS OF HUMAN-WILDLIFE CONFLICT ON LOCAL LIVELIHOOD: CASE STUDY, KIMBI-FUNGOM NATIONAL PARK CAMEROON
}

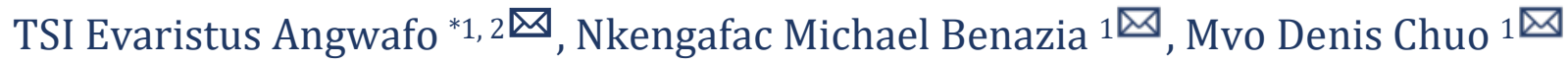 \\ ${ }^{1}$ Department of Forestry, Faculty of Agronomy and Agricultural Sciences (FASA), P. 0. Box 222 \\ Dschang, University of Dschang, Cameroon \\ ${ }^{2}$ Department of Fundamental Science Higher Technical Teacher Training College (H.T.T.T.C.) P.O. \\ Box 39 Bambili University of Bamenda - Cameroon
}

DOI: https://doi.org/10.29121/granthaalayah.v8.i5.2020.54

Article Type: Case Study

Article Citation: TSI Evaristus Angwafo, Nkengafac Michael Benazia, and Mvo Denis Chuo. (2020). IMPLICATIONS OF HUMANWILDLIFE CONFLICT ON LOCAL LIVELIHOOD: CASE STUDY, KIMBIFUNGOM NATIONAL PARK CAMEROON. International Journal of Research -GRANTHAALAYAH, 8(5), 146-157.

https://doi.org/10.29121/granthaa layah.v8.i5.2020.54

Received Date: 05 May 2020

Accepted Date: 31 May 2020

\section{Keywords:}

Human-Wildlife Conflict

Integrated Conservation

Development Project

Kimbi-Fungom National Park

Livelihood

Sustainable Wildlife Management

\section{ABSTRACT}

This study entitled "implications of human-wildlife conflict on local livelihood in the Kimbi-Fungom National Park" was undertaken to assess impacts of Human-Wildlife Conflict (HWC) in the Park so as to provide basis to design a sustainable wildlife conservation roadmap. Data collection was done using questionnaires, semi structured interviews and direct observations. Collected data were treated using excel and statistical package for social sciences (SPSS version 14). Findings revealed that, 98\% of the population experience human-wildlife conflicts that negatively impacted local livelihood, with cumulative average financial losses amounting to $1,97,890 \mathrm{FCFA} /$ year/acre (0.40ha) for the six common staple food crops, and an average cumulative surface area damage of 4.75 acres/year (0.19ha). It was revealed that great proximity to the Park edge bear the highest cost of the conflict. Though losses varied with different crop and distance from the Park, this was attributed to population pressure that intensifies farming activities along the Park edge that greatly threatened the sustainable management of wildlife in the study area. It is against this background that an Integrated Conservation Development Project is proposed for a sustainable wildlife management roadmap that would have to confront the drivers of conflict by working hand-in-hand with all stakeholders concerned towards a win-win outcome.

\section{INTRODUCTION}

Wildlife contributes directly or indirectly to the state of local livelihood. Impacts of human wildlife conflicts (HWC) can range from injury, death, loss of crops and livestock, damaged infrastructure, disease transmission on humans and wildlife (Tangie et al., 2018). Human transformation of the global landscapes in his land-use process has changed the natural environment from predominantly wild to predominantly anthropogenic over the last centuries and has created competition between humans and wildlife for space and resources and has reached an unprecedented stage (Walpole, 2003). As wildlife habitat becomes more and more fragmented, wildlife gets confined

(C) 2020 The Author(s). This is an open access article distributed under the terms of the Creative Commons Attribution License, which permits unrestricted use, distribution, and reproduction in any medium, provided the original author and source are credited. 
into smaller pockets of uncomfortable habitat; humans and wildlife are increasingly coming into contact and in conflict with one another (Madden, 2008; Lamarque et al., 2009). A wide variety of wildlife comes into conflict with farming activities for search of resources and so cause crop damage and wildlife mortality (Madden, 2008). Humaninduced wildlife mortality affects the population, and has wider environmental impacts on ecosystem equilibrium and biodiversity conservation (Tchamba, 1996).

Nowadays, the involvement of needs and aspirations of local communities is widely regarded as of fundamental significance for the sustainable management of biodiversity. Today, the Northwest region of Cameroon has many wildlife reserves but the Kimbi-Fungom National Park (K-FNP) is the only national park of the region with abundant flora and fauna species. It can boss of more than six different species of monkeys, most of which fall within the IUCN red list, buffalos, and other primates (Tata, 2011; Eyebe, 2012; Nsainyi 2015; IUCN Cameroon program info, 2015). Njiforti \& Tchamba, (1993), in an article titled "Conflicts in Cameroon, Parks for or Against People" asked whether plants and animals were meant for man or man was meant for plants and animals. This question was posed because the indigenous people of a water-stressed environment suffered in the hands of conserved wildlife. And, while the population is not allowed to hunt the animals from the Parks, the hungry animals from the Park invade the neighbouring farmlands, damaging crops thereby undermining the fragile rural livelihoods.

Conflict between wildlife species and human society is most often identified by the amount of monetary loss this causes, leading to significant livelihoods impacts. Though this problem is global, their effect on communities is rarely equal. The degree of Vulnerability is a supporting or undermining factor to the desired conservation outcomes (Lambi et al., 2012). It is actually unrealistic for protected areas and people to co-exist in accord when they are not well rewarded for their agreement to limit access into natural resources area and for losses incurred due to crop and livestock depredation. The increasing numbers of filed complaints against Buffaloes lately may generate antagonism against conservation in the K-FNP area.

As in other parts of the world, in Cameroon, large herbivore and primates have been causing damage to agricultural produce. A wide variety of pest herbivores, primates and small mammals have been reported to be in conflict with humans along some protected areas in Cameroon (Tchamba \& Foguekem, 2012; Ebua, 2011; Tangie et al., 2018). Despite the presence of similar animals within the K-FNP (Mvo and Tsi, 2017c), in Cameroon no study has been carried out on the status of human-wildlife conflict in the recently created K-FNP where large herbivores and primates like buffaloes and baboons feature. The role played by this human-wildlife conflict in exacerbating conservation-versus-development debates requires urgent consideration. It is against this background that this study was carried out to assess the implications of human-wildlife conflict in the Kimbi-Fungom national Park, North West Cameroon.

\section{MATERIAL AND METHODS}

\subsection{THE LOCATION OF THE STUDY AREA}

The Kimbi-Fungom National Park (K-FNP) is a more recent National Park created under Prime Ministerial decree number 2015/0024/PM of 3 February, 2015 covering a total surface area of 95,380 ha. This Park is an association of two onetime reserves that were created in $2^{\text {nd }}$ May 1936 as the Fungom Native administration Forest Reserve, (Forestry Ordinance, 42 of 1936) and 1964 as Kimbi Wildlife Sanctuary. These two reserves existed with respective sizes of 327.25 sq. $\mathrm{m}$ and $51.4 \mathrm{~km} 2$ (Nsanyi, 2015; Mvo \& Tsi, 2017). The Kimbi-Fungom national Park cut across 4 Sub-divisions (Fonfuka, Fungom, FuraWa, and Misaje) and 3 divisions (Boyo, Menchum, and DongaMantung.) The KFNP is limited to the east by coordinates: 660700UTM, to the South by Coordinates: 720500UTM, to the West by 590900UTM and to the North 760500UTM. It has an extensive international boundary with Nigeria from Northeast to West making it a transboundary national park. It shares a common boundary to the West with Kashimibila Game Reserve of Nigeria and to the east with Dumbo Cattle Ranch. The major neighbouring villages are kimbi to the south, Zhoa-Nkang in the centre, Esu - Gayama to the west, and Furuawa to the North. These villages also serve as major Entry points (gateways) into the Park. National Development Priority Plan (PNDP) Reports 2010 of Zhoa (Fungom), Fonfuka, Furu-awa, Misaje and Ako Councils put the population of neighbouring villages to the KFNP to 15,000 inhabitants living in 25 small villages dispersed in all these 4 sub divisions (figure 1). 


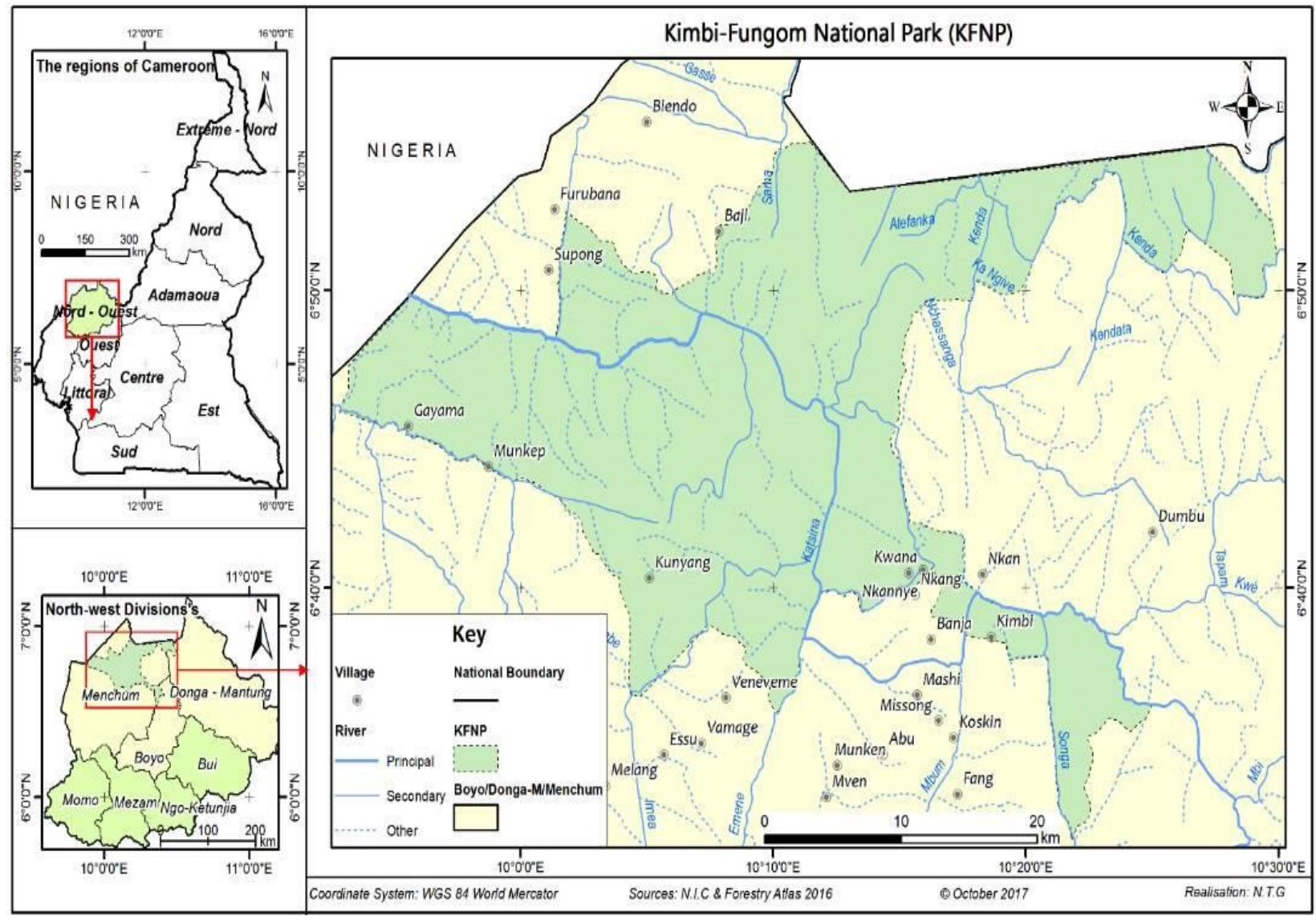

Figure 1: Map of the Kimbi-Fungom National Park, (Source: NIC and Forestry Atlas, 2017)

These divisions are dependent on the cultivation of crops and the raising of animals. The increased human population has perpetuated the dynamism in its land uses today. This has put more pressure on the available land (Balgah and Zeh, 2016).

\subsection{DATA COLLECTION AND ANALYSIS}

The research population for this study was a cross section of persons, animals or objects that were of interest to the researcher (MINFOF, MINEP MINADER currently working in the K-FNP area) and local inhabitants that included key informants (the chief and village headmen). Moreover; the household was preferred as the sampling unit and interviews were restricted to one respondent per household. At each village, the most senior member of the household present was asked for permission to conduct the interview, and asked to participate. Women deferred to men in seniority and culture, so interviewees were predominantly male, but interviews were conducted with women where they were happy to do so. No-one of appropriate seniority that was approached refused to participate in the survey. All interviewees were adults and self-classified into 18-25, 26-33, 34-41, 42-50 and above 51 years.

A case study design was employed that helped for making direct observations and collect data in natural settings (Bromley, 1986). A preliminary survey took place in the month of June 2017, to select the sampling zones, using stratified random sampling based on the presence of serious human wildlife conflict areas in different designated compartments of the park (K-FNP annual report, 2016). Three randomly selected compartments composed of 18 small villages that border the K-FNP was prioritized. These villages were further grouped and stratified in to three categories base on their proximity to the K-FNP edge as near $(<0.5 \mathrm{~km})$, medium $(0.5-1 \mathrm{~km})$ and far $(>1 \mathrm{~km})$. Of this stratification, three different villages per category were randomly selected to get the total number of villages to be sampled. After getting the total number of household heads living in each selected village from the local council, chiefs and quarter heads, $30 \%$ of household per village were sampled based on the total number of households in the sampled village (Table 1). 
Table 1: Total number of sampled households per village and the percentage of sampled households

\begin{tabular}{|l|l|c|c|}
\hline $\begin{array}{l}\text { Category } \\
\text { of } \\
\text { Distance }\end{array}$ & $\begin{array}{l}\text { Sampled } \\
\text { villages }\end{array}$ & $\begin{array}{c}\text { Estimated Number of households using household mapping } \\
\text { per village (source: the different village chiefs, quarter } \\
\text { heads and councils) }\end{array}$ & $\begin{array}{c}\text { 30\% of sampled household to } \\
\text { administer questionnaires }\end{array}$ \\
\hline$<0.5 \mathrm{~km}$, & Kimbi & 122 & 36 \\
\hline & Nkang & 88 & 26 \\
\hline & Kwept & 88 & 26 \\
\hline \multirow{3}{*}{$0.5-1 \mathrm{~km}$} & Fungom & 80 & 24 \\
\hline & Esu & 110 & 33 \\
\hline$>1 \mathrm{~km}$ & Dumbep & 102 & 30 \\
\hline & Buabua & 150 & 35 \\
\hline & Mashi & 104 & 24 \\
\hline Total & 09 & 80 & 275 \\
\hline
\end{tabular}

From the Nine (9) sampled villages comprising a total of 924 estimated household numbers, a 30 percent of each village households were sampled to have a total of 275 people that were interviewed. These sampled populations were randomly selected using the table of random numbers after obtaining information from the village leaders on those having farmland in major conflicting zones of the locality. From the selected households, each household selected only one individual above the age of 18 to be interviewed. Strictly only people above the age of 18 years were targeted as they had good memory of their surroundings. To accompany the household survey, discussions were made with two groups of randomly selected 5-10 respondent per group in each sampled village under the guidance of an interpreter.

Independent assessment of crop damage was done through examination of the portion of crop plants destroyed or fruits relative to the standing total number of crop plants or fruits on the farm. The percentage of crops loss per year was set as the dependent variable and distance to park edge were identified as independent variables. For fear of any biased conclusions on economic estimations, calculations were limited to food crops only to ensure a contrast of the three categories of distance from park edge (WWF, 2007).

Based on crop production records (per acre/plant) obtained at the Funfuka sub divisional delegations of MINADER, Average yield in (kg/year/acre) for a given crop was estimated. The quantity yield from the estimated damage area was multiplied by the cost price of the produce to obtain the overall amount lost to wildlife in that season (Poghon, 2015; WWF, 2007). The costs price of the different agricultural produce damaged were estimated through a market prices appraisal in the sampled communities (villages) and certified by the Funfuka sub divisional delegations of MINADER. The formula below was exploited to work out the financial losses per crop.

\section{$\mathrm{Li}=\mathrm{Ai} \times \mathrm{Yi} \times \mathrm{Mi}$.}

Where:

$\mathrm{Li}=$ Loss of a given crop (kg/year) incurred by households

$A=$ Average Area damaged by pest wildlife for a given crop

$\mathrm{Yi}=$ Average yield in (kg/year/acre) for a given crop

$\mathrm{Mi}=$ Average market price in FCFA/Kilograms/crop

The average prices (CFA) of crops grown in the study area are given below in Table 2.

Table 2: Average market price of common staple food crops as of September, 2017 in the KFNP area

\begin{tabular}{|l|c|c|c|}
\hline $\begin{array}{l}\text { Staple food } \\
\text { crops }\end{array}$ & $\begin{array}{c}\text { Average Price } \\
\text { FCFA/kg and bunch }\end{array}$ & $\begin{array}{c}\text { Average Yield per acreAnnual Average value in CFA per crop } \\
\left(4046 \mathrm{~m}^{2} / \mathrm{kg} / \text { year }\right)\end{array}$ & 40500 \\
\hline Maize & 150 & 270 & 54000 \\
\hline Beans & 200 & 270 & 36000 \\
\hline Cassava & 300 & 120 & 54000 \\
\hline Groundnuts & 200 & 270 & \\
\hline
\end{tabular}


Implications of Human-Wildlife Conflict on Local Livelihood: Case Study, Kimbi-Fungom National Park Cameroon

\begin{tabular}{|l|c|c|c|}
\hline Plantains & 1800 & 14 & 25200 \\
\hline Banana & 500 & 20 & 10000 \\
\hline
\end{tabular}

The collected data were organized into different topics with respect to the objectives of the study and coded according to the topics already described. They were then entered into Microsoft excel and SPSS sheets and analyzed in line with the objective. Based on the research questions, themes were acknowledged from the data and given meaning. Finally, field data results were presented in the form of tables, figures, frequencies, and percentages.

For analysis of the Value of average crop-loss per year, a multiple regression analysis to determine if the reported value of crops loss per year was related to the individual farms' distance to the park edge was made.

\section{RESULTS}

The research was interested in identifying the size of farmland cultivated average annual income from the sales of agricultural products since it shown how wild animals impact the food security/insecurity problem and further determines the livelihoods of the local people.

\subsection{LANDOWNERSHIP AND COMMON FARMLAND SIZES IN THE K-FNP AREA}

Of the nine sampled villages, there existed some disparities in the domain of land ownership. In the Kimbi village for example a good number of respondents never had land on their own but rented or begged for land to cultivate as they only came for settlement after the famous lake Nyos disaster. This was rather not the case with the other two sampled villages. Survey reports from respondents of Kimbi village showed how they are more vulnerable as their limited portions of farmland are located at the park edge. Generally, out of the 262 respondents who admitted having farmland, $69 \%$ had less than 2 acres of farmland; $28 \%(n=77)$ had more than 2 acres and only the traditional rulers (1.6\%) had above 5 acres (Table 3).

Table 3: Size of Farmland owned by respondents (in acres)

\begin{tabular}{|c|c|c|c|}
\hline & Farm sizes in Acres Frequency & Percent \\
\hline Valid & Below 2 acres & 185 & $69.5 \%$ \\
\hline & $>2-5$ acres & 77 & $28.9 \%$ \\
\hline & Total & 262 & $98.5 \%$ \\
\hline Missing & NA & 4 & 1.5 \\
\hline Total & & 266 & 100.0 \\
\hline
\end{tabular}

Farmland sizes in the K-FNP area are said to be generally limited for any kind of large scale agricultural activities as reported to be very and more often in isolated patches. As noted during the survey, the undulating nature of the Park environment pushed farming activities to be more concentrated along the river beds of the Kimbi River. This was common with vegetable cultivation where a farmer will happily own 4 ridges of cultivated land. Farmers were equally seen moving for more than 5hours to reach their farmlands along the river plains. This limitation of land was one of the main drivers of conflict within the Kimbi compartment of the Park. Farmer lamented on their inability to secure food for their families as they were pushed away from their usual farmland.

\subsection{IMPACT ON DIFFERENT AGRICULTURAL PRACTICES}

As noted during the survey, the main subsistence crops damaged were maize, groundnuts cassava, beans, plantain and banana (six very important staple food crops whose loss seriously compromised food security, income and thus livelihood). 64\% ( $n=167)$ and 19\% $(n=49)$ of respondents exclusively base their agricultural activities on crop cultivation and livestock rearing respectively, while $17 \%(\mathrm{n}=46)$ are into a kind of mixed farming.

Comparatively, food crop farmers experienced the highest proportion of average annual crop loss amounting to $64 \%$, of this, $11 \%(n=18)$ lost more than $75 \%-100 \%$ of the yearly produce, $14 \%(n=24)$ lost between $50 \%-75 \%$ of their annual farm produce, $31 \%(n=52)$ of these food crop farmers lost between $25 \%-50 \%$ while $44 \%$ loss between 
$0-25 \%$ of their food crop annually. This is however significantly different with other agricultural activities like livestock farming. From the field results livestock farmers represented 19\% of respondents, of which 55\% lost between 0 to $25 \%$ of their stocks, $29 \%$ averagely lost between $25 \%-50 \%$ of stocks annually while only $8 \%$ of livestock farmers averagely lost $50 \%-75 \%$ and $75 \%-100 \%$ of their stocks annually.

When asked about livestock depredation, some cattle grazers $(9 \%)$ reported that livestock loss to carnivores was not really a big cause for concern as they keep sight of their livestock assisted by dogs. Their major cause for concern is when valuable loss by Buffalos crosses their cows because they usually die during calf birth. Buffalos were also blamed for challenging and killing Bulls to take over the Cow. One of the cattle grazers reported the proliferation of highly resistant ticks from Buffalos to cow. It was noted that calf, kid, lamb, foal and piglets easily fall prey to Hyena and snakes as they approach the park. Hawks and rodents were responsible for the loss of domestic birds. The influx of livestock into the Park for grazing and water is a common problem that was identified by the study. The problem is created by the communities as they keep many animals in very small pieces of land that they own. This causes them to seek grazing inside the protected area. The results of these findings revealed a significant difference (ANOVA, $x^{2}=.944, \mathrm{df}=2, \mathrm{p}=<0.5(0.010)$ ) in term of average annual loss between the three major agricultural activities as hypothesized prior the study.

\subsection{MONETARY COST OF AGRICULTURAL PRODUCE DEPREDATED BY WILDLIFE}

In villages sited within distances of less than $0.5 \mathrm{~km}$ from the park edge, the mean area damaged ranged from 0.25 acres to 0.5 acres, between $0.5 \mathrm{~km}$ and $1 \mathrm{~km}$, it ranged from 0.1 acres to 0.4 acres; likewise, park communities located beyond $1 \mathrm{~km}$ from the park edge had their average area damaged ranging from 0.1 acres to 04 acres. Therefore, the collective average farmland area damaged by wildlife depredation in the three categories of distance from the park was within the average surface area of 1.58acres. By ranking, communities less than $0.5 \mathrm{~km}$ from the park, groundnuts was $1^{\text {st }}$ reporting a percentage of $27 \%$ with a financial value loss of 21,600 cfa/acre/year, maize ranked $2^{\text {nd }}$ with a percentage of $25 \%$ with a financial value of $20,250 \mathrm{cfa} /$ acre/year. Table 4 below shows the different depredated crops in the study area against their different financial losses per year per acre for communities sited below $0.5 \mathrm{~km}$ from the park edge.

Table 4: Annual Average Financial losses from wildlife depredation within $<0.5 \mathrm{~km}$ from Park edge

\begin{tabular}{|c|c|c|c|c|c|}
\hline Crops & $\begin{array}{c}\text { Average Yield per } \\
\text { acre }\left(4046 \mathrm{~m}^{2} / \mathrm{kg} /\right. \\
\text { year })\end{array}$ & $\begin{array}{l}\text { Average area } \\
\text { depredated } \\
\text { (acres) }\end{array}$ & $\begin{array}{l}\text { Ranking of } \\
\text { average }\end{array}$ & $\begin{array}{c}\text { Annual average financial area loss } / \\
\text { acres depredated (CFA) }\end{array}$ & $\begin{array}{l}\text { Ranking of } \\
\text { financial loss }\end{array}$ \\
\hline Maize & 270 & 0.5 & 1 & 20250 & 2 \\
\hline Beans & 270 & 0.25 & 4 & 13500 & 3 \\
\hline \begin{tabular}{|l|} 
Cassava \\
\end{tabular} & 120 & 0.3 & 3 & 10800 & 4 \\
\hline Groundnuts & 270 & 0.4 & 2 & 21600 & 1 \\
\hline \begin{tabular}{|l|} 
Plantains \\
\end{tabular} & 14 & 0,4 & 2 & 10080 & 5 \\
\hline Bananas & 20 & 0.5 & 1 & 5000 & 6 \\
\hline Total & & 1.95 & & 81230 & \\
\hline
\end{tabular}

Figure 2 below denotes the statistical representations of heterogeneity in average annual monetary lost per crop loss within communities sited in less than $0.5 \mathrm{~km}$ from the park. 
Implications of Human-Wildlife Conflict on Local Livelihood: Case Study, Kimbi-Fungom National Park Cameroon

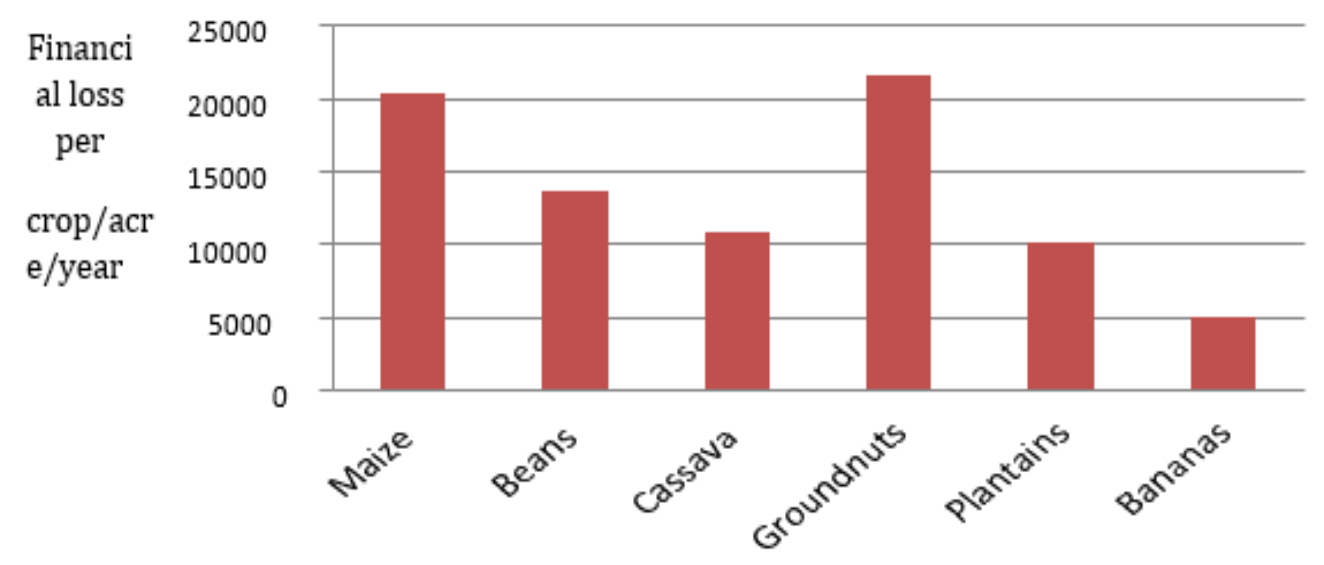

Staple food crops

Figure 2: Financial loss in CFA/crop/acre/year in les then 0.5km from the Park

For communities between $0.5 \mathrm{~km}$ and $1 \mathrm{~km}$, groundnuts were equally ranked $1^{\text {st }}$ with a reported percentage $33 \%$ and a damaged area of 0.4 acres and a financial value of $21600 \mathrm{cfa} /$ acre/year. Bean was ranked $2^{\text {nd }}$ with a reported percentage of $25 \%$ and a damaged area of 0.3 acres and a financial value of $16200 \mathrm{cfa} / \mathrm{acre} / \mathrm{year}$. Table 5 below shows the different depredated crops in the study area against their different financial losses per year per acre within $0.5 \mathrm{~km}$ to $1 \mathrm{~km}$ from the Park edge.

Table 5: Annual Average Financial losses from wildlife depredation within $0.5 \mathrm{~km}-1 \mathrm{~km}$ from Park edge

\begin{tabular}{|l|c|c|c|c|c|}
\hline Crops & $\begin{array}{c}\text { Average Yield per acre } \\
\left(4046 \mathrm{~m}^{2} / \mathrm{kg} / \text { year }\right)\end{array}$ & $\begin{array}{c}\text { Average area } \\
\text { depredated } \\
\text { (acres) }\end{array}$ & $\begin{array}{c}\text { Ranking of } \\
\text { Average }\end{array}$ & $\begin{array}{c}\text { Annual average financial area } \\
\text { loss/acres depredated (CFA) }\end{array}$ & $\begin{array}{c}\text { Ranking } \\
\text { of financial } \\
\text { loss }\end{array}$ \\
\hline Maize & 270 & 0.3 & 2 & 12150 & 3 \\
\hline Beans & 270 & 0.3 & 2 & 16200 & 2 \\
\hline Cassava & 120 & 0.25 & 4 & 9000 & 4 \\
\hline Groundnuts & 270 & 0.4 & 1 & 21600 & 5 \\
\hline Plantains & 14 & 0.2 & 3 & 5040 & 6 \\
\hline Bananas & 20 & 0.1 & 5 & 1000 & 5 \\
\hline Total & & 1.55 & & 64990 & \\
\hline
\end{tabular}

Figure 3 below denotes the statistical representations of heterogeneity in average annual monetary lost per crop loss within communities sited between $0.5 \mathrm{~km}$ and $1 \mathrm{~km}$ from the Park.

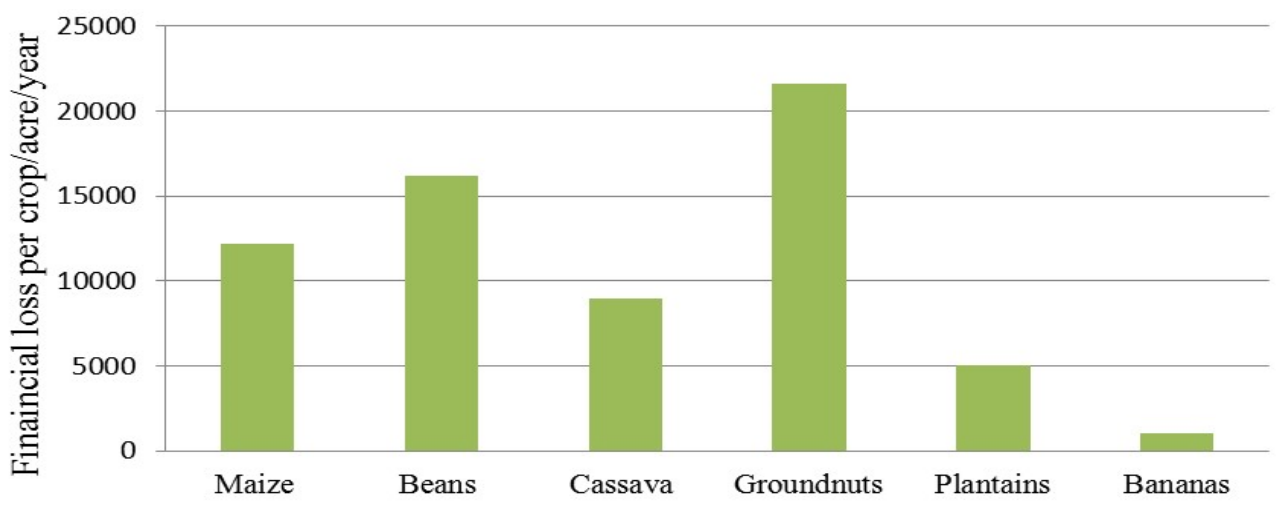

Staple food crops

Figure 3: Financial loss in CFA/crop/acre/year within $0.5 \mathrm{~km}$ to $1 \mathrm{~km}$ from the Park International Journal of Research -GRANTHAALAYAH 
Moreover, for communities beyond a km from the Park edge, groundnuts were ranked 1 st as it represented $31 \%$ in terms of financial losses from raids, showing a financial value of $16200 \mathrm{cfa} / \mathrm{acre} / \mathrm{year}$ with a damaged surface area of 0.3 acre. This crop here was next by maize reporting a percentage of $24 \%$ of financial loss form depredation costing $12150 \mathrm{cfa} /$ acre/year over a 0.3 acres of damaged surface. Table 6 below shows the different depredated crops in the study area against their different financial losses per year per acre for communities sited above $1 \mathrm{~km}$ from the Park edge.

Table 6: Annual Average Financial losses from wildlife depredation within $>1 \mathrm{~km}$ from Park edge

\begin{tabular}{|l|c|c|c|c|c|}
\hline Crops & $\begin{array}{c}\text { Average Yield per acre } \\
\left(4046 \mathrm{~m}^{2} / \mathrm{kg} / \text { year }\right)\end{array}$ & $\begin{array}{c}\text { Average area } \\
\text { depredated } \\
\text { (acres) }\end{array}$ & $\begin{array}{c}\text { Ranking of } \\
\text { Average }\end{array}$ & $\begin{array}{c}\text { Annual average financial area } \\
\text { loss/acres depredated (CFA) }\end{array}$ & $\begin{array}{c}\text { Ranking } \\
\text { of financial } \\
\text { loss }\end{array}$ \\
\hline Maize & 270 & 0.3 & 1 & 12150 & 2 \\
\hline Beans & 270 & 0.2 & 3 & 10800 & 3 \\
\hline Cassava & 120 & 0.25 & 2 & 9000 & 4 \\
\hline Groundnuts & 270 & 0.3 & 1 & 16200 & 1 \\
\hline Plantains & 14 & 0.1 & 4 & 2520 & 6 \\
\hline Bananas & 20 & 0.1 & 4 & 1000 & 6 \\
\hline Total & & 1.25 & & 51670 & \\
\hline
\end{tabular}

Figure 4 below denotes the statistical representations of heterogeneity in average annual monetary lost per crop loss within communities sited above $1 \mathrm{~km}$ from the Park.

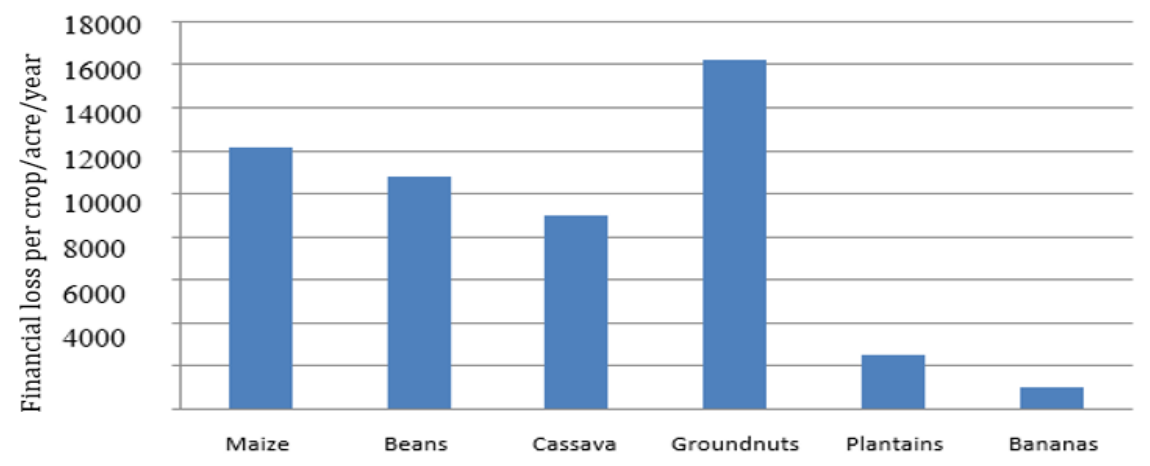

Staple food crops

Figure 4: Financial loss in CFA/crop/acre/year above $1 \mathrm{~km}$ from the Park

Thus, the quantity loss in terms of monetary value is higher for communities located at less than $0.5 \mathrm{~km}$ than the for the other categories of distances from the Park edge due to their greater proximity to the Parks sphere. Figure 7 below shows a graph of distance to the Park edge, with a distribution dominated by close proximity to Park edge.

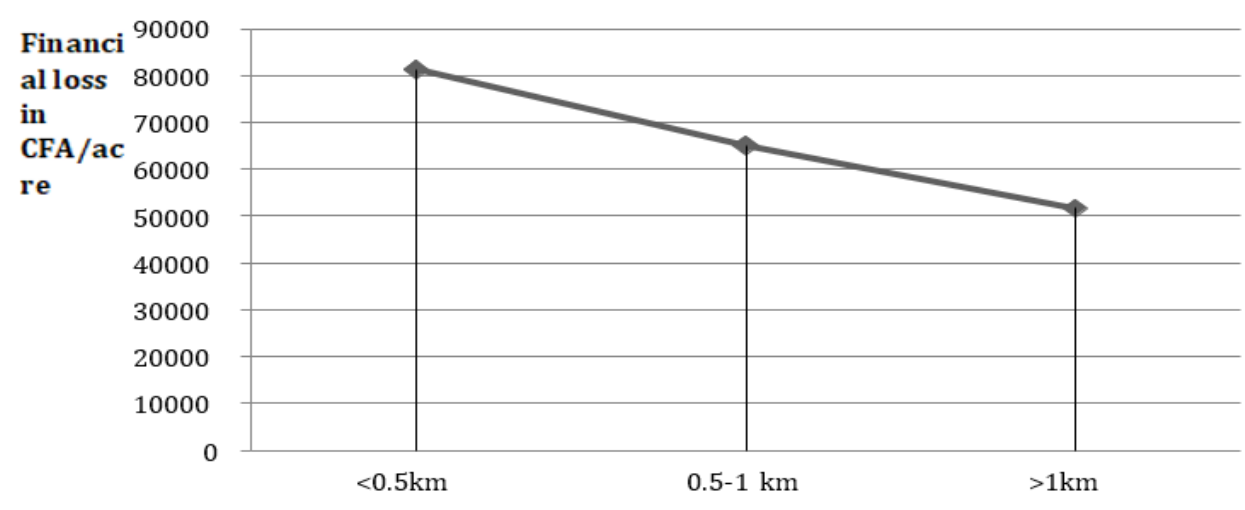

Distance from Park edge

Figure 7: Trend of financial loss with distance from the Park edge 
Implications of Human-Wildlife Conflict on Local Livelihood: Case Study, Kimbi-Fungom National Park Cameroon

Local livelihood is impacted by this conflict with cumulative average financial losses amounting to $1,97,890 \mathrm{fcfa} /$ year/acre for the six common staple food crops, over an average cumulative surface area damage of 4.75acres/year, with great proximity to the park edge bearing the highest cost. Though losses varied with different crop and distance from the Park, groundnuts and maize represented $32 \%$ and $24 \%$ of average financial loss respectively. From this, a significant determinant of livelihood was availability of food for household consumption.

\subsection{HUMAN WILDLIFE CONFLICT AND LOCAL LIVELIHOOD}

The most significant determinant of livelihood was availability of food for household consumption. More than 98\% of the respondents mentioned that they face food shortages attributed to crop raiding by the wild animals from the park. Regarding the household incomes, $90 \%$ of the respondents' experience low incomes from agricultural activities since a significant fraction of the crops grown are destroyed by the crop raiders (animal and birds). All respondents interviewed indicated that crop raiding has promoted poverty in the area, especially from the creation of the K-FNP Park.

Wildlife depredation has been a discordant issue between the Park administration and the local communities, whose livelihoods depend on either agriculture or livestock or both. The farmers have to bear heavy losses due to crops damage and livestock predation threatening the sustenance of their livelihood. When the population were asked on their chances of benefiting from any compensation scheme, $100 \%$ of the 262 respondents who revealed cases of wildlife depredation responded by stating that they were never compensated for the losses incurred in the conflicts with wildlife. The farmers expressed their dissatisfaction toward the absence of any compensation scheme. Information on how HWC has impacted the livelihood of farmer's was gathered in an attempt to answer the fourth research question which helped evaluate the effects of crop and livestock raiding on farmer's livelihoods in the KFNP. The data indicate that crop raiding has adversely affected the livelihoods of many people living around the park. More than $98 \%$ of the population adjacent to the Park was noted to have their livelihoods affected. This is associated with food and livestock dearth, insecurity and low income of households as indicated in table 6.

This research work was also interested in identifying the size of farmlands, crop raiding, average annual crop and livestock loss and agricultural output sale. The findings of the study indicate that the destruction of crops in the farmland contribute significantly to the food insecurity problem which further determines the livelihoods of the local people. It also affirms the fact that crop loss to animals has contributed greatly towards low income generation within communities. In some instances, farmers lose a whole garden particularly in areas highly infested with baboons, Tantalus monkeys, Buffalos and rodents, which inflict profound and potentially appalling losses. In situations where farmers guarded their crops, the children were most often forced to escape from school so to guard the crops.

Another appalling situation noted during the survey period was the recurrent search of lost teenagers inside the Park. Prior to the creation of the park the local population had successfully linked up their different settlement sites with foot paths passing inside the Park. The creation of the Park with no alternative road network to replace their usual footpaths fueled the conflict in the sense that, wild animals with time noted the absence of poacher. As stipulated by 'Bubeeh' Francis

"Wild animals especially Baboon and Buffalo are no longer afraid of women and children like before...Baboons today behave like men planning a rape incident as they regularly chase young girls to the point of them getting lost in the bushes". A case in point is Chia Fabiola, a 14years female student who got missing for 23 days in the Park after an attack from a Baboon. It impacts negatively the livelihood of the local community as much time is usual dedicated during harvesting season to search missing children while crops are being raided further in the farms.

\section{DISCUSSION}

Local livelihood is impacted by this conflict with a strong correlation to proximity to Park edge. From this, significant determinant of livelihood was availability of food for household consumption. This could be explained by the fact that, most of the farmlands within $0.5 \mathrm{~km}$ from the Park were located just too close to the Park. For communities located between $0.5 \mathrm{~km}$ and $1 \mathrm{~km}$ a large majority had their farms close to the Park but not as close as that of the aforementioned. In the last category of farm distance from the Park $(>1 \mathrm{~km})$, the farmlands were further 
TSI Evaristus Angwafo, Nkengafac Michael Benazia, and Mvo Denis Chuo

from the Park and had much of their crops damaged mostly by rodents and birds. The higher depredation rates within the first category of distance from the Park edge $(<0.5 \mathrm{k})$ was possibly cause by Buffalo raid and primate species who easily migrate out of the Park in-search of drinking water and fresh pasture during the dry season and the presence of palatable crops like maize during both seasons as farmers prefer cultivating river banks. Climate change that affected rainfall patterns within the year, is one of the explanations that can be given for this preference of river beds for cultivation. Climate change has caused the dry seasons to get longer and sometimes the rain become unpredictable. Research findings by Nyhus et al. 2003 and Lambi et al., 2012 equally revealed the role that environmental changes have in accelerating the incidences of HWC that further jeopardises the standard of living among local communities.

The findings of the study indicate that the destruction of crops in the farmland contribute significantly to the food insecurity problem which further determines the livelihoods of the local people. It also affirms the fact that crop loss to animals has contributed greatly towards low income generation within communities. Tchamba \& Foguekem, (2012), confirms this view that production of highly palatable and nutritious seasonal crops such as maize, which attracts wild animals, induces heavy losses and therefore high guarding investments. In some instances, farmers lose a whole garden particularly in areas highly infested with baboons, Tantalus monkeys, Buffalos and rodents, which inflict profound and potentially appalling losses. Nchanji, (1998), reported that crop looting is a serious problem as crop raiding animals can have a disturbing impact on the standard of living of peasants whose entire survival is dependent on subsistence agriculture. He anticipated that in situations where farmers guarded their crops, the loss incurred was 30\% and where there was no guarding at all, it was 98\%. In a similar study, WWF, 2007 noted that in some cases, there was rigorous food shortages, increase food prices, famine and morbidity increased what's more the rural agricultural society becoming poorer and poorer, with the greater part of children not going to school. In situations where farmers guarded their crops, the children were most often forced to escape from school so to guard the crops.

Generally, it was noted that the respondents perceived a worst situation in their livelihood with the creation of the Park. This is in contrast with the findings of Mwakima, (2005) in her study in IlNgwesi Community and Sweet Waters Game Sanctuary in Laikipia District. She found out that, despite, the presence of human wildlife conflict in the two study areas, the local population felt that the benefits received from wildlife far outweighed the losses caused by wildlife and that benefits had led them to appreciate wildlife better.

\section{CONCLUSION}

HWC in the K-FNP area is causing significant loss on farmers' production. Groundnuts and Maize were the highest vulnerable crop to damage whereas chickens, goat and sheep were the most vulnerable livestock. The trend of crop damage and incidence of HWC was a function of distance from the Park edge. On bases of direct observation, the present study estimated an average financial loss amounting to 1, 97,890 FRS CFA/acre/annum (0.4046ha) and an estimated average area damage of $4.75 \mathrm{acre} / \mathrm{year}(0.19219 \mathrm{ha})$. The absence of any commensurate means of compensating victims of problem wildlife species due to budgetary constraints has continuously building up negative conceptions, making the conflict frequent in different directions and multifaceted. Never the less; in suggesting preferred strategies to curb these HWC, most respondents insisted on the fact that an alternative livelihood be provided to them. This factor is largely influenced by the limitation of valuable farmlands in the locality as a large part of preferred river bed in most villages is within the Park and sending them to farm in upland area will not yield much in terms of farm output. Thus their wish to diversify their sources of livelihood. Ndenecho, 2009, in his research work in the onetime Kimbi Game reserve proposed a similar strategy to assist local inhabitants. Development of land use plans for individual land exploiters in the ecosystem and the enhancement of community participation in wildlife conservation for socio-economic empowerment should be highly prioritized within the Kimbi-Fungom national Park area.

Finally, managing this intricate HWC requires an Integrated Conservation Development Projects with innovative, practical and cost-effective solutions. Local perception change for a peaceful co-existence of all stakeholders will require a solution to all factors impacting local livelihood. Thus addressing the roots of humanwildlife conflict will necessitate a parallel check on all related factors in the ecological, economic, political, and social issues like food security in line to guarantee sustainable wildlife management. 
Implications of Human-Wildlife Conflict on Local Livelihood: Case Study, Kimbi-Fungom National Park Cameroon

\section{SOURCES OF FUNDING}

None.

\section{CONFLICT OF INTEREST}

We declare that there is no conflict of interest regarding the publication of this paper.

\section{ACKNOWLEDGMENT}

I give glory to God Almighty for empowering me with strength and the determination spirit to accomplish this piece of work. Many thanks are due to all people who assisted me in carrying out this study. I thank in a very special way the Staff of Kimbi-Fungom National Park and the Conservator, Mr. KIRENSKY MBI Jerry and his predecessor, Mr. Christopher FOMINYAM and traditional authorities as well as all the respondents in the sampled villages who either responded to questionnaires or attended the focus group discussions sessions.

Beers, S. R., \& De Bellis, M. D. (2002). Neuropsychological function in children with maltreatment-related posttraumatic stress disorder. The American Journal of Psychiatry, 159, 483-486. doi: 10.1176/appi.ajp.159.3.483.

\section{REFERENCES}

[1] Chuo, M. D., \& Tsi E. A. (2017a). Chimpanzee in Ethno-Primatological Practices and It Implications for Biodiversity Conservation: Kimbi-Fungom National Park and KomWum Forest Reserve, Cameroon. American Journal of Agriculture and Forestry. 5(5):157-172 http://www.sciencepublishinggroup.com/j/ajaf. pp. 111

[2] Chuo, M. D., \& Tsi E. A. (2017b). Influence of Traditional Beliefs on the Conservation of Pan troglodytes ellioti: Case Study, Kimbi-Fungom National Park and Kom-Wum Forest Reserve, NW Region, Cameroon. International Journal of Forest, Animal and Fisheries Research (IJFAF). [Vol-1, pp. 1-11. https://dx.doi.org/10.22161/ijfaf.1.3.1

[3] Chuo, M. D., \& Tsi E. A. (2017c). Status of large mammals: case study of gorilla, (Gorilla gorilla diehi), chimpanzee (Pantroglodytes ellioti) and buffalo (Syncerus caffer), Menchum South, NW Cameroon. International Journal of Environment, Agriculture and Biotechnology $\quad$ (IJEAB).Vol-2, $\quad$ Pp 1-11. http://dx.doi.org/10.22161/ijeab/2.4.11

[4] Chuo, M. D., \& TSI, E. A. (2018). Propose Strategies to Enhance the Biodiversity Status and Traditional Knowledge Systems Relevant for the Conservation of Pan Troglodytes ellioti in the Kimbi-Fungom National Park and Kom-Wum Forest Reserve.International Journal of Advanced Engineering, Management and Science.Vol-4, https://dx.doi.org/10.22161/ijaems.4.4.15. Pp 321-350.

[5] Ebua, V. B., Tsi, E. A.,\&Nguedem, S. F. (2011). Attitudes and perceptions as threats to wildlife conservation in the Bakossi area, South West Cameroon. International Journal of Biodiversity and Conservation Vol. 3(12), pp. 631-636. Available online at http://www.academicjournals.org/IJBC

[6] Ebua, V.B., Tamungang, S. A., Tsi, E. A., \& Nguedem, S. F. (2013). Impact of Livelihood Improvement on the Conservation of Large Mammals in the Bakossi Landscape, South West Cameroon. Greener Journal of Agricultural Sciences.Vol. 3 (1), pp. 033-038. www.gjournals.org.

[7] Eyebe, A. J., Abe Eyebe, A. S., Angu, K. A., \& Endamana, D. (2012). Integrating Biodiversity Conservation into National Development Policy: A case study of Cameroon, PCLG Discussion Paper No 09.

[8] Eyebe, A. J., Dkamelaand, P. G.\& Endamana, D. (2012). Overview of human wildlife conflict in Cameroon. Poverty and Conservation Learning Group Discussion Paper, no 05, pp.423.

[9] Lamarque F. J., Anderson R., Fergusson M., Lagrange Y., Osei-Owusu. (2009). Human-wildlife conflict in Africa Causes, consequences and management strategies, Food and Agriculture Organization of the United Nations, Rome, Italy. 
[10] Lambi M. C., Kimengsi J. N., Kometa G. C., \& Tata E. S. (2012). The Management and Challenges of Protected Areas and the Sustenance of Local Livelihoods in Cameroon, Canadian Centre of Science and Education, Department of Geography, University of Buea, Cameroon. Pp. 1-29.

[11] Madden, F. (2004). Creating Coexistence between Humans and Wildlife: Global Perspectives on Local Efforts to Address Human-Wildlife Conflict. Human Dimensions of Wildlife, 9: pp247-257.

[12] Mwakima, M. W. (2005). Opportunities and constraints towards sustainable ecotourism in Kenyas Rangelands the Case of IL Ngwesi Communal Ranch and Sweet.

[13] Nchanji, A.C., \& Lawson D.P. (1998). A survey of Elephants crop damage around the BanyangoMbo wildlife sanctuary 1993-1996-page 96 Cameroon Biodiversity Project and Wildlife Conservation Society, Yaounde, Cameroon.

[14] Ndenecho, E. N. (2009). Ecological Planning and Ecotourism Development in Kimbi Game Reserve, Cameroon. North West Province, Cameroon.Kamla-Raj 27(2): 105-113

[15] Njiforti, H. L., \& Tchamba, M. N. (1993). Conflict in Cameroon: Parks for or Against People? In Njogu J. G. (2012). Wildlife Management and Conservation in View of International Conventions in (ed), The Kenya wild Life Service in the 2st century: Protecting globally significant Areas and Resources, p109-106. In the George Wright Forum volume 29 number 1.

[16] NSainyi, M. S. (2015). Report on the North West Regional Wildlife Service's Coordination Meeting Held in Esu, Zoa Sub-division. Tropical Plant Exploration Group (TroPEG). Mundemba, Cameroon.

[17] Nyhus, P., Fisher, H., Madden, F., \& Osofsky, S. (2003). Taking the bite out of wildlife damage: the challenges of wildlife compensation schemes. Conservation in Practice No 4. PP 39-41.

[18] Poghon, J. K. (2015). Assessment of Economic Cost of Human/Elephant Conflict in Tsavo Conservation Area, Kenya,Veterinary Science, University of Pretoria.

[19] Tangie, S. N. A., Tchamba, N. M., Tumenta P. F., Tsi, E. A., \& Mvo D. C. (2018). Human Wildlife Conflict: Causes, Consequences and Management Strategies in Mount Cameroon National Park South West Region, Cameroon. International Journal of Forest, Animal and Fisheries Research (IJFAF) [Vol-2, Issue-2, https: //dx.doi.org/10.22161/ijfaf.2.2., www.aipublications.com.ISSN: 2456-8791. pp. 1-49.

[20] Tata, F. T. (2001). Stakeholder Participation in the Establishment of Biosphere Reserves:The Case of Local Communities in the Proposed Kimbi-Dumbo-Nyos Conservation Zone, Cameroon. Dresden, Germany.

[21] Tchamba, M. N. (1996). History and Present Status of the Human/Elephant Conflict in the WazaLogone Region, Cameroon, West Africa. Biological conservation. 75, pp35-41.

[22] W.W.F. (2007). A case study on human wildlife conflict in Nepal. WWF International. Nepal. Pp.25.

[23] Walpole, M., Karanja, G. G., Sitati, N. W., \& Leader, W. N. (2003). Wildlife and People: Conflict and Conservation in Masai Mara, Kenya. Wildlife and Development. International Institute for Environment and Development. London. Series No.14, pp 27-37. 